\title{
The Influence of Internet Social Media on the Chinese Political System
}

\author{
Zhang Lei ${ }^{1, a}$ \\ ${ }^{1}$ College of Public Affairs, Zijingang Campus of Zhejiang University, Hangzhou, Zhe Jiang, China \\ alei_zhang@zju.edu.cn
}

Keywords: Internet Social Media, Political Culture, Political System, Netizens

\begin{abstract}
The Chinese government and its citizens have begun to interact more and more due to the proliferation of social media. This paper analyzes the influence of internet social media on the Chinese political system through system theory and political culture theory. The Chinese political system is mainly controlled by the Chinese Communist Party (CCP) and the political culture in China has been a subject political culture. However, since the growth of internet social media, citizens have increased open access to express their opinions about politics. Through two typical case studies, this paper concludes that the political culture is changing through the social internet media, but that it cannot influence the absolute power of the Chinese government. The Chinese political system, in the one-party state, has control over the internet social media and the current political system will not be largely influenced by the social internet media, especially when citizens are more concerned with their economic development and wealth.
\end{abstract}

\section{Introduction}

China is a communist country, which has a very unique political culture and political regime. Since the appearance of the Internet, the way that citizens interact with the government has been changing. As opposed to following the elite classes' orders and instructions, the Chinese people have started to express their own opinions through the internet, and even protest publicly against the government. Citizens' behavior has raised the government's attention, which has contributed to the government adjusting their attitude towards the public. In a way, the Chinese political culture seems to be changing as a result of the internet media; a more open and compromising political culture seems to be forming.

Much research has been done about how the Chinese political structure reformed, how the Chinese Communist Party takes control of the 1.3 billion people. Also, many Chinese scholars pay attention to the development of the Chinese internet, and many suggestions about how the government should react to Chinese netizens to better serve its citizens. However research of internet social media with the political system theories has seldom been done. This paper seeks to research on the influence of internet social media on the Chinese political culture and political system by treating the internet social media as an input element of the whole Chinese political system, and analyze the possible outputs that could be generated after input processed by this system.

Through case studies, the influence of the internet social media can be analyzed comparatively, showing that internet social media has brought little change to the Chinese political system. Although the government is always immediately responding to hot internet events, the Chinese political system has not been challenged by the internet social media. Instead, the internet social media promotes citizen's passion to participate in politics, which contributes to a promising political culture, but Chinese political system will keep stable, and can use internet social media to better maintain its control over the country.

\section{Literature Review}

A political system is like other systems, which can be generalized and studied by scientific approaches. A political system has its inputs, and processes these inputs to generate outputs. In 
David's view, a political system is always dynamic, and only persists if the system works effectively to take in certain inputs and export out policies or decisions under necessary support ${ }^{[1]}$. Political systems have different levels. A government is a set of institutions that are ordered in hierarchy to play different roles in political processes. A regime, which consists of fundamental principles or rules in a society that shapes how the government runs, is more permanent than a government ${ }^{[2]}$. Culture shapes people's goals and ways of action, within which people feel what they ought to be. Political culture refers to a particular distribution of cognitive, affective, and evaluative orientations toward a political system or political object. In China's subject political culture, citizens understand what their roles are, but they are not able to express their opinions but led by the government ${ }^{[3]}$. These are political theories that have been discussed in western society.

After the Chinese Communist Party formed the new Republic of China, China has been a one-party ruling state for over 70 years. As Kerry and Martin said, "rather than being rigidly hierarchical and authoritarian, which is often the assumption, political power in China now is diffuse, complex, and at times highly competitive" ${ }^{[4]}$. Having over 1.3 billion citizens, the one-party system has been criticized by many western scholars that it lacks democracy and constrains the basic voting right. A truth is that over many years, the CCP has controlled the public media and information reaching the public, certain levels of propaganda did exist ${ }^{[5]}$.

But after the population of the internet, it is barely possible for the CCP and the Chinese government to selectively reveal information to Chinese citizens. Internet tools especially microblogging service applications such as Weibo or Wechat, which are usually called internet social media, have significantly expanded the dissemination of information about social issues ${ }^{[6]}$. Over the last decades, although the basic regime of China has remained constant, the public sphere of this rapidly urbanized and modernized Chinese society has been more and more compromised.

There have been many studies about the new technologies, or the internet population, the public participations of Chinese politics, or how Chinese media is influencing the government. For example, Cara Wallis concludes that young Chinese people have integrated media technologies into their life and communities. New modes of civic participation have challenged the established rules including political processes due to the emergence of internet media ${ }^{[7]}$. Clay Shirky claims that media tools have been used all over the world for citizens to access information and put up their opinions ${ }^{[8]}$. However, research has seldom been done about whether internet media, especially self-managed media, will influence the Chinese political culture or even push a new kind of reform on China's political system.

The Chinese political system is like an human body system, the Chinese Communist Party has been the ruling brain in China, in the Chinese political system, there are also three main actors co-existing with the CCP. The central state government operates as the bone of the Chinese political system, and penetrates into every area of China, implementing and administering China's state business ${ }^{[9]}$. The Liberation Army acts as the fists of the Chinese political system, which defends China's territory and national sovereignty, keeps Chinese society stably running through force. Lastly, the National People's Congress is where all important rules and policies are directly made and published ${ }^{[10]}$.

The Chinese state consists of five distinct territorial-administrative levels. At the top, directly below the center are the provincial-level units. Beneath the provinces, the second level consists of municipalities and prefectures. The third level consists of counties, below which the fourth level consists of townships and villages. At the bottom of the administrative hierarchy is the hamlet ${ }^{[11]}$.

Thus, the operating mechanism of the Chinese political system can be summarized as: the top CCP governors make national policies under the guarantee of liberation Army against any chaos, the hierarchical government executes these policies, and collects feedback from the mass, then policies are amended to better develop the whole country and maintain the political system stably running.

I conducted my research on internet-based social media and analyzed what this media has brought to China's political culture and system. I investigated this through three research questions:

(1) Why are Chinese citizens making comments on political events on the internet instead of 
exchanging their opinions with the government directly and face to face?

(2) Has the government changed its operating mechanisms to cope with this phenomenon?

(3) Will the political culture be changed gradually due to self-managed media such that Chinese citizens will start to protest for their voting rights, and the political system will start to form a new shape?

\section{Case Study}

\subsection{Case Introduction}

In this section, two cases will be introduced, then they will be comparatively analyzed with the system theory and political culture theory.

(a). The Wei Zexi event

In April 12, 2016, a 21-year old college student named Wei Zexi died of cancer. Before he died, this college student wrote a blog in Zhihu, which is a blogging platform with thousands of millions users. In his blog, he criticized China's biggest search engine company, Baidu. During his cancer treatment, he searched the Baidu website about the best hospital that could treat his fatal disease. But it was discovered that the hospital recommended by Baidu had bribed Baidu in order to appear first in Baidu's search result list. Wei Zexi died after useless treatment in this hospital after he ran out of 200,000 Chinese Yuan. Later in May, his blog was read and forwarded by millions of netizens on the internet social media. Baidu Company, the hospital and the capital group behind the hospital, and even the government were criticized and hurl abused by millions of netizens. But this event gradually quieted down after several months, the only change was that Baidu Company changed its method of advertisement recommendation after government officials demanded Baidu's policy change. The hospitals lost a certain degree of trust by the patients but still got their income of health treatment. The government did intervene in the event, but played the role of a mediator.

(b). The Di-club's organizational comments on Facebook

The Di-club is an internet user blog club where netizens gather together to exchange their opinions by commenting on certain events or people. In January 20, 2016, thousands of Di-club netizens commented on SetTV News and Apple Daily's Facebook homepage, criticizing these newspapers for their Taiwan independence speeches. Before Di-club's organizational comment behavior, the central Committee of the Communist Young League published a poem written by the first president of the People's Republic of China, Mao Zedong, which was seen as a signal that encouraged Chinese netizens to criticize Taiwan's independence speeches. Many netizens hurl abused Taiwanese people in the name of patriotic support, and the Chinese government gave a tilted attitude about these netizens' speeches, which implicitly pushed nationalism. This event caused no real effects but was more like a widespread joke amongst Chinese netizen, just like any other hot spots on the internet social media, the event disappeared in several weeks.

\subsection{Introduction about the System Theory and Political Culture}

System theory was developed by David Easton, the central question is how political systems manage to remain stable in an environment full of instability and change. In Easton's view, it is necessary to examine how the political system interacts with the environment within and outside of society. All actions and conditions that are not political are viewed as environmental. Easton assumes that every single person in society has certain desires, such as wealth, health, power. These are important reasons why a political system exists in the society; the political system regulates legislated rules that ensure that every person's desires are satisfied without chaos ${ }^{[12]}$. Figure 1 illustrates the concept and operating mechanism of the political systems. 


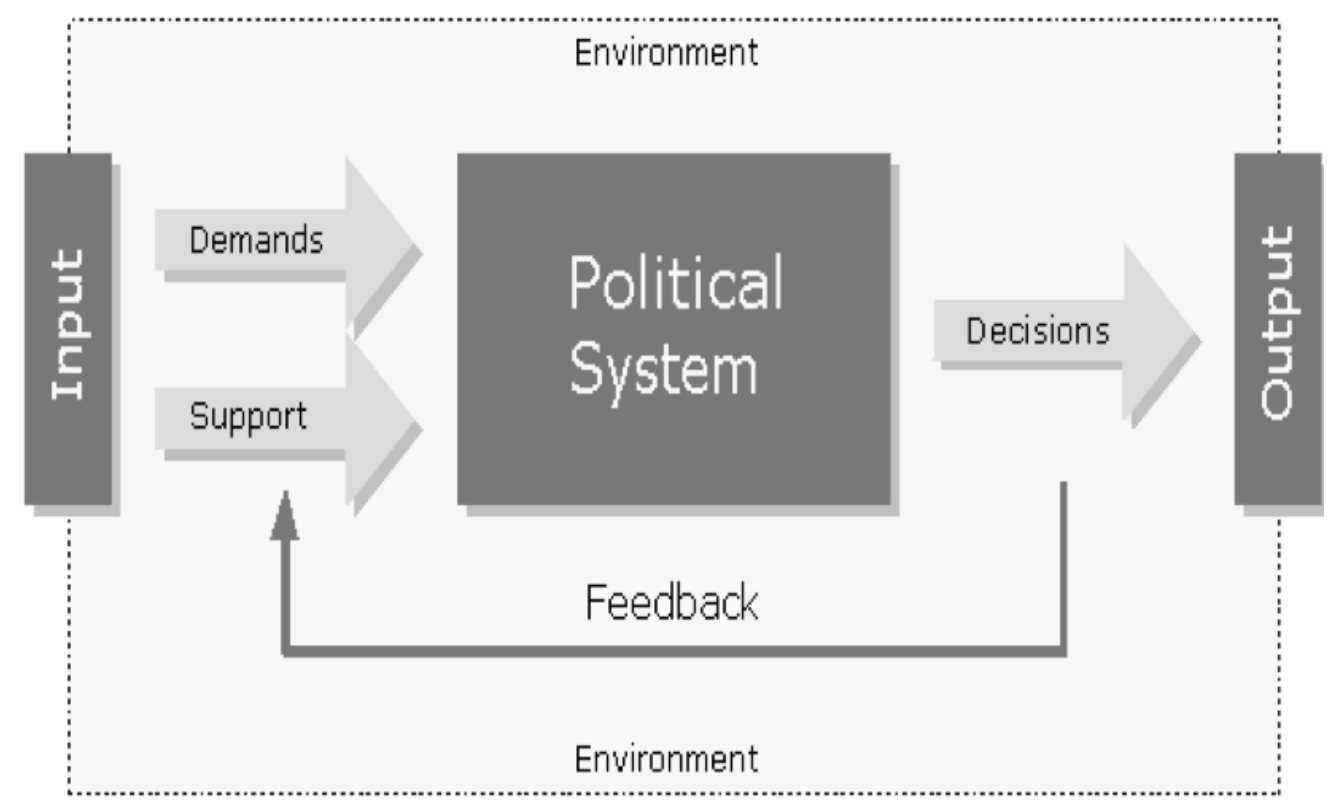

Figure 1 Elements of a political system and surrounding environment ${ }^{[13]}$

Political culture can be seen as a branch of the whole social culture of a country. Every culture places particular emphasis on some special aspects of behavior, which explains people's attitudes towards the political system they live in ${ }^{[14]}$. For example, loyalty, modesty and obedience are aspects that Chinese culture values.

\subsection{Comparative Analysis of the Two Cases}

For the Wei Zexi event, from the start it was revealed to the public by the very victim himself. Then people got to know what happened to this poor college student. People were not only compassionate about Wei Zexi's bitter experience, but more afraid of the same things happening to themselves. Deep in this fear, netizens started to pour their comments, which were mostly hurl abuse, on the social media. In this process, many of them did not realize what they were really up to.

For the Di-club's organizational comments on Facebook, this kind of events are more often happening in internet social media. Netizens are more willing to get some funny news and laugh at them. They commented on the Taiwan newspaper in the name of country and patriotism, but they were not really determined to achieve political results. Their efforts were not really to help China achieve its national unity, no real demands for change of the Chinese political system were made.

From the system theory, the demand of government supervision and criticism can be seen as input to the Chinese political system. But not all demands can be political issues that cause the political system to cope with them. Some demands can be simply wiped out with time and minimal explanations ${ }^{[15]}$.

\subsection{The Influence of Internet Social Media on Political Culture and Political System}

A very common cultural phenomenon in internet social media is called "onlooking” which means netizens participate in events, which are not really related to them, by gossiping. These two kinds of events happened on the internet social media are really typical. The Wei Zexi event stands for those events that could really hurt netizens. Once this kind of events appears on the social media, netizens pay special attention and wait for the process of the government. If the explanation given is satisfying, then the event gradually settles down. The political input of netizens' demands does not really threaten the stability of the political system. If there are some voices strongly asking the government to improve the political system, another phenomenon appears: these voices will be cleared from the social media by the government ${ }^{[16]}$. The Di-club comment event stands for daily gossiping culture. Netizens are not really trying to achieve a certain result, but to pass their time and 
have some fun, hardly impacting on the Chinese political system.

Considering another aspect of the political system, support for the system is necessary to keep it running. When certain inputs are given to the system, if support for these inputs is much less than the power that keeps the system stable, then inputs can be neglected or suppressed by the system to keep its original stability ${ }^{[17]}$. Thus, under the one-party control state, the impact of netizens on the internet social media has not influenced the stability of the Chinese political system. Most of the netizens' demands can actually be satisfied by economic solutions. In a way, they are actually chasing wealth. So the Chinese political system still has the absolute power to maintain its stability, but simply requires some extra time and energy to comfort millions of netizens.

\section{Conclusion}

People are using internet social media to access the latest information, communicating with their friends and even strangers. The government is also publishing decisions and expressing their opinions on certain social events. The internet social media influences people's daily lives, and also their political participation. This paper researched on the influence of internet social media by using system theory and political culture theory to analyze two typical cases on the internet social media.

The internet social media provides people with access to attract the government's attention. But how the government reacted and what kind of consequences the internet social media had caused reflect the government's real attitude toward internet social media. There are all kinds of criticisms on the social media about how bad the Chinese political system is when people cannot get proper treatment, but there are not many voices asking citizens to do something to change the political situation. Citizens do not appeal to changing the government, but hope the government to change itself and protect them.

The Chinese political system has maintained its stable running in the past several decades, while the internet social media has strengthened the connections between the Chinese government and Chinese citizens. It promotes a more open political culture, provides Chinese people with a convenient and instant platform to attain political information, and pushes the Chinese government to restrict itself to maintain citizens' trust. But the internet social media is under control of the government, thus it cannot weaken the control of the Chinese political system over China and Chinese people current and in the near future as long as the government will not release its power voluntarily.

\section{Reference}

[1] Easton D. (1957). An Approach to the Analysis of Political Systems. World Politics, Vol.9, No.3, p383-400.

[2] Mayo, H. B. (1954). The Political System: An Inquiry into the State of Political Science. Canadian Journal of Economics \& Political Science, 20:272.

[3] Chilton, S. (1988). Defining Political Culture [J]. The Western Political Quarterly, 41(3), pp 419-445

[4] Kerry, D, \& Martin, F. M. (2011). Understanding China’s Political System. Current Politics and Economics of Europe, Vol. 20, No. 2

[5] Shirk, S. L. (2011). Changing Media, Changing China. Oxford University Press, Inc. New York.

[6]Lei, Ya-wen. (2011). The Political Consequences of of the Rise of the Internet: Political Beliefs and Practices of Chinese Netizens. Political Communication, 28:3, 291-322

[7] Wallis, C.(2011, May). New Media Practices in China: Youth Patterns, Process, and Politics. International Journal of Communication, 406-436

[8] Shirky, C. (2011,January). The Political Power of Social Media, Technology, the Public Sphere, and Political change. Foreign Affairs, 90(1):28-41. 
[9] Liang, Q. (2002). On the Political Environment-On the Relationship between the Political Environment and the Political System Concurrently. Journal of Chengdu University (Social Science), (4).

[10] David, S. (2008, December). Training China's political elite: the Party School system. The China Quarterly, pp. 827-844.

[11] Wedeman, A. (2001). Incompetence, Noise, and Fear in Central-Local Relations in China. Studies in Comparative International Development Winter, Volume 35, Issue 4, pp 59-83

[12][13] Easton, D. (1979). A Systems Analysis of Political Life[J]. British Journal of Sociology, 14.

[14] Solomon, R. (1971). Mao's Revolution and the Chinese Political Culture. University of California Press, pp. 516-521

[15] Bimber, B. A.(2011). Information and political engagement in America: The search for effects of information technology at the individual level. Political Research Quarterly, 54.

[16] Zhang, X. (2011). Seeking Effective Public Space: Chinese Media at Local Level[J], China An International Journal, 5(1):55-57

[17] Falkinger J. \& Grossmann, V. (2005). Institutions and Development: The Interaction between Trade Regime and Political System[J]. Journal of Economic Growth, 10(3):231-272. 